\title{
STUDENTS THOUGHT PROCESSES IN PHYSICAL EDUCATION: A MULTI-DIMENSIONAL ANALYSIS
}

\author{
Pereira Paulo Silva ${ }^{1 *}$ \\ Carreiro da Costa Francisco ${ }^{2}$ \\ Diniz J osé Alves 3 \\ ${ }^{1}$ Porto Polytechnic, Rua Dr. Roberto Frias, n 602, 4200 - 465 - Porto, Portugal \\ 2,3Technical University of Lisbon, Estrada da Costa, 1499-002 Cruz Quebrada, Portugal
}

Keywords: thought processes, students, Physical Education, gender, socioeconomic level.

\begin{abstract}
This study examines students thought processes in Physical Education (attention during classes, orientation of target achievement, causal attributions of results, attitudes towards discipline, competence perception, perception of the discipline's goal's, degree of satisfaction towards classes). This study involved 198 students from the 9th grade. Data were collected by use of questionnaires. The results show that students have: i) high levels of attention during classes, ii) a stronger orientation to the ego than to the task; iii) a favorable attitude towards PE iv) a good perception of competence in PE v) a high level of satisfaction regarding PE classes vi) the variables examined did not vary according to students socio-economic background; vii) there are significant differences in ego orientation, competence perception in PE among female students and male students viii) the variables of thought processes are, in general, positively and significantly correlated.
\end{abstract}

\section{Introduction}

In recent years a very significant part of the research on teaching, both in general and in Physical Education, was built around the paradigm of learnercentered mediators processes (commonly known as the paradigm of student thinking). Strongly influenced by cognitive psychology, the paradigm of learnercentered mediators processes based on the premise that learning doesn't take place in an automatic way starting in school. From the standpoint of this model, teacher's behaviors are considered catalysts of students mediating responses and are not exactly the direct causes of learning (Doyle, 1986). It is assumed, hence the existence of a dual relationship: one between teaching and student's thoughts, and the other between student thoughts and their learning (Marcelo, 1994). This means, as indicated by Wittrock (1986), that this research program

\footnotetext{
*E-mail: PPereira@ese.ipp.pt;
} 
assumes that teaching affects students learning through their thought processes. From the student's mediational paradigm point of view, learning is understood as a constructive activity that depends predominantly on the students. In fact, in this model the student is conceived as an active subject in shaping is own learning process (Carreiro da Costa, 1996), given that he filters the learning incentives addressed to him and deals with them in its own way (Landsheere, 1994). Also Lee (1997) draws attention to the fact that the student is an active participant in the classroom that influences the events and interactions in it, as they also affect him. Investigations under this paradigm have as main object of study the implicit processes that students use to mediate the instructive incentives and produce learning outcomes (Piéron, 1999a). More specifically, and as Wittrock (1986) tells us, the purpose of the investigations developed in the context of the mediational paradigm of the student is to ask about the effect of teachers and teaching in perceptions, expectations, attention, motivation, attribution, memory, beliefs, attitudes, learning strategies and students' metacognitive processes involved in their performance. However, most investigations that had as their object of study the thoughts of Physical Education students focused exclusively around one or two cognitive processes (attitudes, motivation, ...), if not simultaneously sought to examine various mental processes. The simultaneous analysis of a wide range of cognitive processes is important because only this way is possible to determine whether there are interactions between them. Thus, we establish the following objectives for this investigation: a) analyze students thought processes in Physical Education (attention during classes, orientation of achievement goals, causal attributions of results, attitudes towards discipline, competence perception, perception of the discipline's goals, degree of satisfaction towards classes), b) verify if the variables of gender and socio-economic level of students families influence their thought processes, c) understand how students different thought processes in Physical Education, above mentioned, are interrelated.

\section{Material and methods}

Subjects. A total of 198 students from the $9^{\text {th }}$ grade took part in this study, 93 were male (47\% of the total) and 105 females (53\%). The average age of the students is 14.6 years. Most students come from low class families (56.6\%), according to the categorization of Simões (1994) for the Portuguese population.

\section{Instruments:}

1. Attention - This variable was measured using a technique similar to that developed by Locke and Jensen (1974) and used in the study by Lee, Landin and Carter (1992). The students were requested to describe the thoughts that were having in four different teaching situations: a) the teacher presents the lesson objectives or talks about the task, b) the teacher demonstrates the task c) students practice a given task d) students complete a global activity. After a signal (whistle) the student stopped the activity and replied in writing to the following question: "What were you thinking at the moment just before the whistle?". 
2. Orientation of achievement goals in Physical Education - To assess this variable, we used an adapted version to the context of Physical Education of the Perception of Success Questionnaire (Roberts \& Balague, 1989; Roberts, Treasure \& Balague, 1998). This instrument consists of 12 items, six of which measure the task orientation and the other 6 measure the ego orientation. Responses to these items are presented in Likert format of 5 points. The internal consistency of the questionnaire, examined using the Cronbach's alpha coefficient, was of .89 for the items sub-scale of ego orientation and .90 for the items sub-scale of task orientation.

3. Causal attributions of results in Physical Education - The analysis of the most important causes that students use to explain their results (or ratings) in Physical Education was made through the Questionnaire of Causal Attributions of Results in Physical Education (QACREF), which we built and validated. This instrument consists of two distinct parts. In the first part we tried to meet the students' perceptions about the results or rankings that they usually get in Physical Education. The second part comprised a set of causes that could explain such results (ability, effort or commitment, luck, discipline and teacher). 4. Attitudes towards Physical Education - This variable was analyzed using the Student Attitudes Questionnaire towards Physical Education (QAAEF), which we built and validated. This questionnaire contained two dimensions: 1 students taste for Physical Education and its raw and satisfaction / pleasure in this discipline classes (7 items), 2 - the importance of Physical Education (3 items). It was adopted in the questionnaire a response scale of the Likert type of 5 points. The internal consistency of the questionnaire, examined using the Cronbach's alpha coefficient, was of.91.

5. Competence Perception in Physical Education - To measure the perception that the student has about his competence in Physical Education, we used an adapted version of the Academic Self-Concept in Physical Education Scale (ASCPES) of the instruments Academic Self Description Questionnaire (ASDQ) I and II (Marsh, 1990, 1992). This scale consists of six items, each item featuring six possible answers. The internal consistency of the scale, assessed by Cronbach's alpha coefficient, was of 90.

6. Perception of Physical Education goals - To assess this variable we used the Questionnaire on Students' Perception of Physical Education goals (QPAOEF), built by ourselves. In this questionnaire students are asked that, from among a set of five targets (health, physical condition, learning skills, entertainment, social relations within the class) choose in descending order of importance the three main goals that Physical Education should pursue.

7. Degree of satisfaction towards Physical Education classes - To assess this variable, we used a questionnaire developed by Carlier, Radelet and Renard (1991). It contains only one question: "Did you like the class that just finished?". Procedures. The assessment instruments of the variables orientation of achievement goals, causal attributions of results, attitudes towards Physical Education, competence perception in that discipline, perceptions of Physical 
Education goals were administered during the Physical Education classes. Attention during classes was analyzed during two Physical Education classes in four different teaching situations. The degree of satisfaction during classes was also evaluated in two classes, at the end of them.

Statistical treatment of data/ data statistical treatment

All data used the student as the unit of analysis and were treated by the statistical treatment SPAD-N (Système Portable pour l'Analyse des Données). We used the Cluster Analysis which is a multivariate statistical technique.

\section{Results and Discussions}

Attention during classes. Each student was asked four times in the classroom during two classes, which makes a total of 1584 recorded reflections on the subject of attention or students thoughts. The reading of the results listed in Table 1 shows that most of the time during Physical Education classes students focus their attention on aspects related to the task (64.2\%). Below, in descending order but with a much lower frequency, student's attention is directed towards factors related to class (14.4\%). Thirdly, in Physical Education classes students focus their attention on elements (physical and psychological) related to their own (8.0\%). Fourth, the data show that students thoughts during Physical Education classes are geared for immediate extra-curricular elements, ie, unrelated to the class (7.8\%). It should be noted that there was still a significant percentage of student's thoughts during the lessons that were included in the category of attention - not applicable (5.6\%).

Table 1. Frequency and percentages of student's thoughts during Physical Education classes

\begin{tabular}{|l|c|c|c|c|c|c|c|c|}
\hline \multirow{2}{*}{$\begin{array}{l}\text { CATEGORIES AND } \\
\text { SUB-CATEGORIES }\end{array}$} & \multicolumn{2}{|c|}{ BASKETBALL } & \multicolumn{2}{c|}{ GYMNASTICS } & \multicolumn{2}{c|}{ VOLLEYBALL } & \multicolumn{3}{c|}{ ACTIVITIES } \\
\cline { 2 - 10 } & Freq. & $\%$ & Freq. & $\%$ & Freq. & $\%$ & Freq. & $\%$ \\
\hline I - In connection with the & 278 & 68.1 & 194 & 60.7 & 546 & 63.8 & 1018 & 64.2 \\
task & 60 & 14.7 & 45 & 14.1 & 111 & 13.0 & 216 & 13.6 \\
A. Motor skills & 37 & 9.1 & 22 & 6.9 & 72 & 8.4 & 131 & 8.3 \\
B. Observation and & 134 & 32.8 & 97 & 30.3 & 283 & 33.1 & 514 & 32.4 \\
evaluation & 47 & 11.5 & 30 & 9.4 & 80 & 9.3 & 157 & 9.9 \\
C. General skills & 50 & 12.2 & 47 & 14.7 & 131 & 15.3 & 228 & 14.4 \\
D. Instruction & 36 & 8.8 & 27 & 8.4 & 91 & 10.6 & 154 & 9.7 \\
\hline I - In relation to class & 14 & 3.4 & 20 & 6.3 & 40 & 4.7 & 74 & 4.7 \\
E. Class organization & 38 & 9.3 & 29 & 9.0 & 59 & 6.9 & 126 & 8.0 \\
F. Social & 16 & 3.9 & 18 & 5.6 & 23 & 2.7 & 57 & 3.6 \\
\hline III - In relation to himself & 22 & 5.4 & 11 & 3.4 & 36 & 4.2 & 69 & 4.4 \\
G. Physical condition & 26 & 6.4 & 31 & 9.7 & 67 & 7.8 & 124 & 7.8 \\
H. Psychological & 16 & 3.9 & 19 & 5.9 & 53 & 6.2 & 88 & 5.6 \\
condition & 408 & 100 & 320 & 100 & 856 & 100 & 1584 & 100 \\
\hline IV - No relation to class & 26 & & & &
\end{tabular}


These results, taken together, go along the same lines of those observed in other studies (Lee et al. 1992; Locke \& Jensen, 1974; Nunes, 2004). Indeed, Locke and Jensen (1974) concluded in their study that student's attention during Basketball classes, Dance and Tumbling is geared predominantly to the class task (between 59\% and 64\% of verbalized thoughts). Also Lee et al. (1992) pointed that, during Tennis classes, more than half of the thoughts reported by students (57\%) were somehow related to the tasks taught in the class.

Let us turn now to the average levels of student's attention during the four class teaching situations we examined. Generally, students have higher levels of attention when they are performing a given task or a global activity than following teacher's instructions, ie, during the presentation of the class objectives or task or even demonstrating it. The results are consistent with the findings of the investigation carried out by Locke and Jensen (1974).

From the pedagogical point of view, the data reported in this study should be highlighted. We know now that attention is, in general education and in Physical Education, a key variable for student's academic achievement. Hence arises in literature references to the idea that the teacher has an important responsibility in contributing to the enhancement and improvement of student's cognitive process.

Orientation of achievement goals

Table 2 shows the average values obtained by the students not only in the whole subscales of ego and task orientation, but also in each of the questions (or items) that were within.

The average scores obtained by students in sub-items of the scale of task orientation ranged from 4.12 ("When I have a better income for my skill level) and 4.55 ("When I control something I could not do before), therefore being all close to the maximum possible for each item ( 5 points). The average score achieved by students in all subscale of task orientation was 26.05, being close to the maximum possible value of the subscale (30 points). These results suggest us that, overall students present a high level of task orientation in the context of Physical Education. In contrast, in the items that constitute the sub-scale of ego orientation students reported average values ranging from 2.60 ("When I show people that I am the best") and 3.25 ("When my performance overcomes that of my colleagues or opponents), so that the generality of these items is located slightly below or above an intermediate score. In this sense, the average scores obtained by students in all sub-scale of ego orientation were of 17.74, slightly below the midpoint of the subscale (18 points). These data seem to indicate that students in the context of Physical Education do not have high levels of ego orientation.

Through a statistical analysis we noticed if the differences previously detected between the average scores recorded by students insubscales of task orientation and ego were significant. The completion of the related t test has highlighted the existence of significant statistically differences between students scores in the two subscales $(\mathrm{t}=$ 20.64, g.l. $=197, \mathrm{p}<.001)$. 
Table 2. Average values obtained by students in the questionnaire items guidance of achievement goals in PE (adapted version of POSQ)

\begin{tabular}{|l|c|c|}
\hline Items (In practical Physical Education classes I feel I & Average & DP \\
am successful:) & & \\
\hline Subscale of task orientation & 4.19 & .88 \\
(3) When I work intensively & 4.26 & .81 \\
(4) When I express a clear personal improvement & 4.53 & .67 \\
(7) When I overcome the difficulties & 4.55 & .70 \\
(8) When I control something I could not do before & & \\
(10) When I have a performance at the highest level & & .86 \\
of ability & 4.12 & .73 \\
(11) When I achieve a goal & 4.41 & \\
Subscale of ego orientation & & 1.20 \\
(1) When I beat others & 2.70 & 1.23 \\
(2) When I'm the best & 3.09 & \\
(5) When my performance overcomes that of my & 3.25 & 1.17 \\
colleagues or adversaries & 2.60 & 1.05 \\
(6) When I show people that I'm the best & 3.17 & 1.15 \\
(9) When I do something that others cannot do & 2.92 & 1.14 \\
(12) When I'm clearly superior & 26.05 & 3.41 \\
\hline Subscale of task orientation & 17.74 & 5.44 \\
\hline Subscale of ego orientation & & \\
\hline
\end{tabular}

Given the above data, we conclude that in the field of Physical Education students have a greater orientation for the task than for the ego. These results converge with those investigations by Cervelló and Santos-Rosa (2000) and Solmon and Boone (1993).

The main explanation for the fact that students had a greater orientation for the task than for the ego might have to do with what was stated by SantosRosa and Cervello (2000), they state that, in Physical Education classes the objectives identified as priorities aim to promote the active involvement of students in this classes, personal effort and improving the performance from a self-referential point of view, along with the emergence of cooperative components during classes, so to meet the needs of involvement students do not need a high motivation for the ego.

Please note that students predominant orientation for the task can have a positive effect on some of his motivational processes in Physical Education (competence perception, attributions), their behavior or participation in classes (selection of tasks, effort) and the valuation they attach to that discipline (Cervelló Santos-Rosa, 2000; Duda, 1992; Solmon \& Boone, 1993; Tzetzes, Gouda \& Kourtessis Zisi, 2002).

Causal attributions of results in Physical Education

Nearly half of the students (50.5\%) consider they usually achieve, "good" (38.9\%) and "very good" (11.6\%) results in Physical Education. In turn, 47.0\% of the students said that they achieve "reasonable" results in that discipline. Only 
2.5\% of students state that they usually achieve "weak" results in Physical Education. It is interesting that no student feels that achieves "very weak" results in Physical Education.

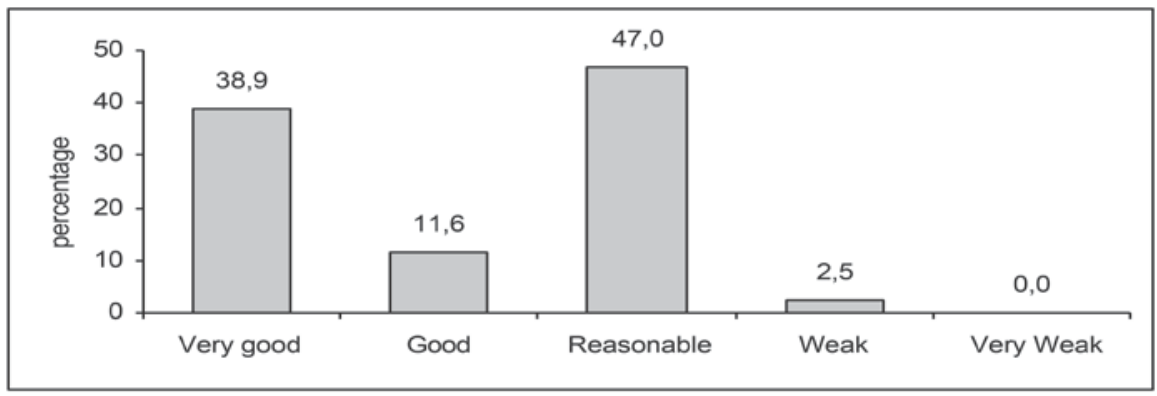

Figure 1. Students perception about the results they usually achieve in $P E$

Let us now examine some of the causes which in the opinion of students may underlie these results. Thus, the vast majority of students said to "agree" or "strongly agree" that their ability to play sports, their commitment to school and the teacher are the main causes that explain the achievement of their results in Physical Education.

In turn, the overwhelming majority of students stated that "agree somewhat" or "disagree" that luck / bad luck plays a central role in the results they get in Physical Education.

In terms of educational activity, it is important to note that in the perspective of the attribution theory of Weiner, the students feel strongly motivated to continue learning when they attribute success or failure to their efforts (unstable cause, internal and controllable) instead of attributing it to causes on which they have little or no control, such as the ability (stable cause, internal and uncontrollable) or luck (unstable cause, external and uncontrollable) (Wittrock, 1986). Moreover, note that according to the same theory, the major motivational problems usually arise when students attribute failures to stable and uncontrollable causes (Woolfolk, 2000).

Students attitudes towards Physical Education

The average scores achieved by students in matters related to Physical Education and its issues and satisfaction / pleasure in classes ranged from 3.79 ("Physical Education is one of my favorite subjects) and 4.33 ("Normally I get bored in Physical Education classes"). These average scores fall slightly above or below the value 4 , and are therefore high, since the score of each item could range from a minimum of 1 to a maximum of 5 points.

Interestingly the average scores recorded by students on the items on the taste for Physical Education and its issues and satisfaction / pleasure in classes are in all cases higher than those obtained by the same questions regarding the importance of Physical Education. 
Pereira Paulo Silva, Carreiro da Costa Francisco, Diniz José Alves/ Gymnasium

Table 3. Average values obtained by the students in the questionnaire items attitudes towards PE

\begin{tabular}{|l|c|c|}
\hline Items & Average & DP \\
\hline Taste for Physical Education and its issues & & \\
satisfaction/pleasure in classes & & \\
(1) I always have fun in Physical Education classes & 4.08 & .91 \\
(3) I like Physical Education & 4.30 & .93 \\
(4) it seems that time passes quickly in Physical Education classes & 4.16 & 1.04 \\
(5) Taste for Physical Education issues (Handball, Gymnastics, & 4.03 & .88 \\
Football, etc.) & 3.79 & 1.28 \\
(6) Physical Education is one of my favourite subjects & 4.33 & .89 \\
(7) Normally I get bored in Physical Education classes (*) & 4.29 & .95 \\
(9) Usually I wish that Physical Education classes end quickly (*) & & \\
\hline The importance of Physical Education & 3.51 & 1.07 \\
(2) Physical Education is an important subject to my overall \\
training & & \\
(8) Physical Education is as important as other subjects & 3.43 & 1.09 \\
(10) Compared to other subjects Physical education is one of the & 3.29 & 1.26 \\
least important to my overall training (*) & & \\
\hline
\end{tabular}

Our results match those obtained in other studies (Delfosse, Cloes, Piéron \& Ledent, 1995; Gonçalves, 1998; Pieroni, Delfosse, Cloes \& Ledent, 1997; Pieroni, Ledent, Delfosse \& Cloes, 2000b; Ryan \& Fleming Maina, 2003; Stelzer, Ernest, Fenster \& Langford, 2004), which have shown that the majority of students express a better attitude toward Physical Education. It is possible that the main reason for this student's favorable attitude lies on the specific characteristics of the discipline itself. In fact Physical Education is a practical subject as opposed to academic subjects referred to as "theoretical" which offer students more freedom and allow movement, being also supported by a playful aspect that is rarely found in school (Piéron, 1999b).

\section{Competence Perception in Physical Education}

In ASCPES items, students reported that the average values ranged from 3.57 ("Comparing myself with my colleagues in the same age, I'm good at Physical Education) and 5.25 ("I'm afraid when I go to Physical Education classes"). Note, however, that the average scores achieved by students in the items are located in most cases around the value 4, which is an intermediate alternative since it is a six-point scale. In turn, over full scale the students achieved an average score of 26.26, putting this value well above the midpoint of the scale (21 points). Given these data, we can say that students generally have a good sense of competence in Physical Education, or in other words feel they are competent in that subject.

Our data go along the same lines of those observed in studies of Gill (1998) and Piéron, Delfosse, Cloes and Ledent (2000a), indicating that approximately one in every two students perceive themselves as "good" or "very good" in Physical Education. 
Table 4. Average values achieved by students on items of competence perception scale PE

\begin{tabular}{|l|c|c|}
\hline Items & Average & DP \\
\hline (1) Comparing myself with my colleagues the same age, & 3.57 & 1.45 \\
I'm good at Physical Education & & \\
(2) I have good marks in Physical Education & 4.30 & 1.26 \\
(3) I have no difficulty in Physical Education & 4.43 & 1.18 \\
(4) I'm afraid when I go to Physical Education classes & 5.25 & 1.20 \\
(5) I learn fast in Physical Education & 4.47 & 1.18 \\
(6) I have always been successful in Physical Education & 4.23 & 1.46 \\
\hline Total ASCPES & 26.26 & 5.71 \\
\hline
\end{tabular}

Let us focus on some of the pedagogical consequences which may arise from this feeling expressed by the majority of students who are competent in Physical Education. Several investigations have shown that competence perception in Physical Education is related to motivation, behavior in class, pleasure or satisfaction in this discipline and participation in extra-curricular physical activity (Carreiro da Costa Pereira, Diniz \& Piéron, 1997; Carroll \& Loumidis, 2001).

\section{Perception of Physical Education goals}

The maintenance or improvement of health arises, according to students, in the first position in the hierarchy of Physical Education goals. Indeed, approximately $45 \%$ of the students think that the most important goal of Physical Education is the improvement or maintenance of health.

Soon after, in descending order of student's preferences appears the goal improving physical condition. For about 33\% of the students improving their physical condition is the main objective of Physical Education.

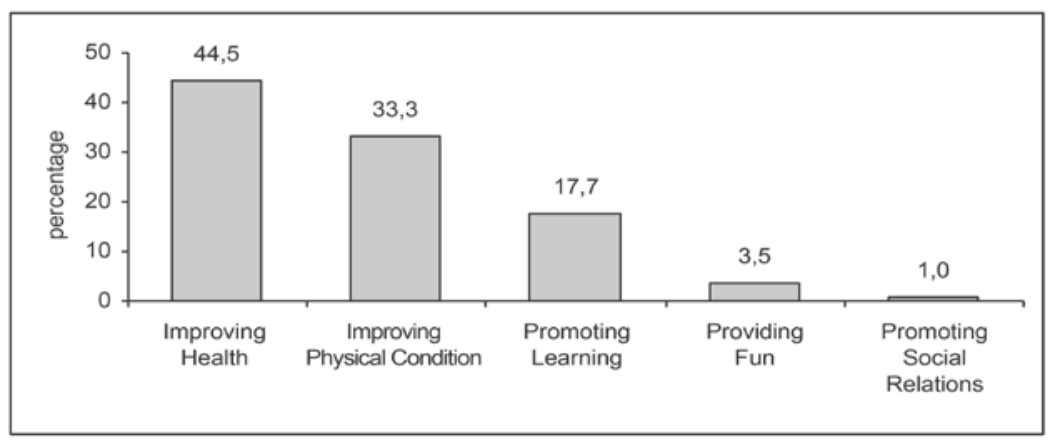

Figure 2. Students perception of Physical Education goals

In students perspective the promotion of learning (skills or sports abilities) occupies the third position in the hierarchy of Physical Education goals (17.7\%). The fun or recreation comes in fourth place in the hierarchy of Physical Education goals, although with a much lower degree of preference to the earlier (3.5\%). Promoting social relationships within the class appears in the bottom of the hierarchy of Physical Education goals. 
With regard to the objective improvement or maintenance of health, the results observed in this study are consistent with the conclusions of the study by Piéron et al. (2000b). In literature the health promotion or health education are often referred to as the main goals of Physical Education. In this context it seems important to introduce the reflection of Bento (1995, p. 149) stating that: "A physical education attentive to the problems cannot fail to elect one of its central guidance to health education. If you want to provide valuable services to student's social education, if you aim to contribute to a productive, creative, successful life, physical education finds in the orientation of health education a means of a realization of their claims, formulations and justifications".

Degree of satisfaction towards classes

A large majority of the students, specifically $40.4 \%$, felt that had enjoyed "a lot" the two classes observed. In turn, $20.7 \%$ of the students reported that they had enjoyed "a lot" one of the classes and "so and so" the other class, while $29.3 \%$ said they liked "so and so" the two classes. Instead, only $1 \%$ of the students said they had not liked "nothing" of the two classes and 1\% who had enjoyed "a little bit" one of the classes and "nothing" the other class. We can say therefore that the majority of students have shown satisfaction with Physical Education classes. The results obtained at the level of student's satisfaction towards Physical Education classes are on the same line of other investigations (Delens Swalus \& Renard, 1987; Gonçalves, 1998; Piéron et al. 2000a).

Effect of students gender and socioeconomic status on their thought processes in Physical Education

Through Cluster Analysis we found that boys are characterized by the perception about the results they usually obtain in Physical Education, an ego orientation in the context of the discipline and a competence perception in Physical Education higher than female students. It should also be noted that the gender of the students does not appear associated to variable attention during classes, task orientation in Physical Education, causal attributions, attitudes towards that discipline, perception of the goals of Physical Education and degree of satisfaction towards classes. These results are not consistent with previous studies that have shown that male students differ significantly from those of females in attention during classes (Locke \& Jensen, 1974), attitudes towards Physical Education (Delfosse et al. 1995; Gonçalves, 1998, Stelzer et al., 2004), perception of the goals of Physical Education (Piéron et al., 2000b) and the degree of satisfaction towards classes (Pieron et al. 2000a; Shigunov, 1991). One possible explanation for this discrepancy may be at the level of the different instruments used for data collection.

Concerning the influence of student's socioeconomic status on their thought processes in Physical Education, we found no difference between the cognitive processes of individuals from different social classes. However, the association between students thought processes and their socioeconomic status is generally recognized in literature. As stated by Siedentop (1998), socioeconomically weaker students usually come to school with fewer basic skills 
and are also disadvantaged in concentration, persistence in performing the tasks and patience when it is time to receive a bonus. Given these disadvantages, students often adopt a negative attitude towards school and a low level of confidence in their abilities to learn for themselves. It is possible that in Physical Education due to the specificity of the discipline, the aspects that distinguish students from different social classes, such as language skills, lifestyle and cultural and family environment, do not exercise a decisive influence on their thought processes, nor are crucial to their learning success.

\section{Interrelationships between thought processes variables}

We wondered how the many variables of the students thought processes in Physical Education were related to each other. Thus, we verified, using the Automatic Assignment, that there are positive and significant relationships between different variables of students thought processes. Student's attention during Physical Education classes is related to the degree of satisfaction to those same classes. The ego orientation in the context of Physical Education appears correlated with task orientation within that discipline, with competence perception in Physical Education and the perception about the results they usually get in that discipline. The task orientation in the context of Physical Education also appears associated with competence perception in Physical Education and with the perception about the results that they usually get in that discipline. Student's perception about the results that they normally achieve in Physical Education is also related to competence perception in Physical Education and to attitudes towards this discipline. Competence perception in physical education also appears correlated with the attitudes towards physical education and the degree of satisfaction towards classes. The variable attitudes towards Physical Education is associated with satisfaction towards classes. Student's perception about the goals that Physical Education should pursue is related to their attitudes towards the discipline.

Table 4. Interrelations between the different variables of students thought processes in PE

\begin{tabular}{|c|c|c|c|c|c|c|c|}
\cline { 2 - 7 } \multicolumn{1}{c|}{} & $\begin{array}{c}\text { Attention } \\
\text { in class }\end{array}$ & $\begin{array}{c}\text { Ego } \\
\text { Orientation }\end{array}$ & $\begin{array}{c}\text { Task } \\
\text { Orientation }\end{array}$ & $\begin{array}{c}\text { Attitudes } \\
\text { Towards PE }\end{array}$ & $\begin{array}{c}\text { Competen } \\
\text { e Perception }\end{array}$ & $\begin{array}{c}\text { Goals } \\
\text { perception }\end{array}$ & $\begin{array}{c}\text { Degree of } \\
\text { satisfaction }\end{array}$ \\
\hline $\begin{array}{c}\text { Attention in } \\
\text { class }\end{array}$ & & & & & & & \\
\hline $\begin{array}{c}\text { Ego } \\
\text { Orientation }\end{array}$ & & + & & & & & \\
\hline $\begin{array}{c}\text { Task } \\
\text { Orientation }\end{array}$ & & + & + & + & & & \\
\hline $\begin{array}{c}\text { Attitudes } \\
\text { towards PE }\end{array}$ & & + & + & + & + & & \\
\hline $\begin{array}{c}\text { Competen } \\
\text { e Perception }\end{array}$ & & & & + & + & & \\
\hline $\begin{array}{c}\text { Goals } \\
\text { perception }\end{array}$ & & + & & & & \\
\hline $\begin{array}{c}\text { Degree of } \\
\text { satisfaction }\end{array}$ & + & & & & & & \\
\hline
\end{tabular}

These data seem to support the thought of Lee and Solmon (1992) when stating that 
student's cognitive processes (attention, motivation, self-concept and perception of teachers education behavior) are not independent of each other, but instead form a complex network of mediators that are interrelated and affect learning.

\section{Conclusions}

From the different analysis carried out, one could suggest the following conclusions:

1 - Most of the time during Physical Education classes students focus their attention on aspects related to the task. Students have higher levels of attention in the classroom in practical situations than in teacher instruction situations.

2 - In the field of Physical Education, students have a greater task orientation rather than an ego orientation.

3 - The majority of students consider that they usually get "good" or "very good" results in Physical Education. In student's opinion, their results in Physical Education are the consequence of causes that can be internal and external, stable or unstable, controllable or uncontrollable.

4 - In general, students have a positive attitude towards Physical Education.

5 - Most of the students have a good sense of competence in physical education.

6 - With regard to physical education goals, students feel that this discipline should primarily pursue, in descending order, "health" and "physical condition" improvement.

7 - Most students show a high level of satisfaction in Physical Education classes. 8 - Students socio-economic level does not influence their thought processes in Physical Education.

9 - There are significant differences in ego orientation in the context of Physical Education, perceived competence in that discipline and attention to results that would normally get in physical education among female students and male. The latter display higher levels in these three variables.

10 - In general the variables of thought processes are positively and significantly correlated.

\section{References}

1. BENTO, J. (1995). O outro lado do desporto, Porto: Campo das Letras;

2. CARLIER, G., RADELET, K., RENARD, J. (1991). Sources de variations des feedback et leur perception par les élèves, Revue de l'Education Physique, 31, 137-176, France, Paris;

3. CARREIRO DA COSTA, F. (1996). Condições e factores de ensinoaprendizagem e condutas motoras significativas: uma análise a partir da investigação realizada em Portugal, Boletim da Sociedade Portuguesa de Educação Física, 14, 7-32, Portugal, Lisboa;

4. CARROLL, B., LOUMIDIS, J. (2001). Children's perceived competence and enjoyment in physical education and physical activity outside school, European Physical Education Review, 7 (1), 24-43, United Kingdom, Chester;

5. CARREIRO DA COSTA, F., PEREIRA, P., DINIZ, J., PIÉRON, M. (1997). 
Motivation, perception de compétence et engagement moteur des élèves dans des classes d' éducation physique, Revue de l' Education Physique, 37 (2), 83-91, France, Paris;

6. CERVELLÓ, E., SANTOS-ROSA, F. (2000). Motivación en las clases de educación física: Un estudio de la perspectiva de las metas de logro en el contexto educativo. Revista de Psicología del Deporte, 9 (1/2), 51-70, Spain, Palma;

7. DELENS, C., RENARD, J., SWALUS, P. (1987). Etude des liens entre la satisfaction des élèves et différents paramètres observés, Sport, 117, 37-43, Belgium, Louvain;

8. DELFOSSE, C., CLOES, M., LEDENT, M., PIERON, M. (1995). Attitudes d'enfants de 6 à 12 ans à l'égard de l'éducation physique scolaire et de ses objectifs, Sport, 149, 35-47. Belgium, Louvain;

9. DOYLE, W. (1986). Paradigmes de recherche sur l'efficacité des enseignants. In M. Crahay \& D. Lafontaine (Eds.), L'art et la science de l'enseignement. Hommage à Gilbert De Landsheere, 435-481, Belgium, Bruxelles: Labor;

10. DUDA, J. (1992). Motivation in sport settings: A goal perspective analysis. In G. Roberts (Ed.), Motivation in sport and exercise, Champaign, IL: Human Kinetics 1 (1), 57-91, USA, Illinois;

11. GONÇALVES, C. (1998). Relações entre características e crenças dos alunos e os seus comportamentos nas aulas de educação física. Dissertação de Doutoramento não publicada. Faculdade de Motricidade Humana, Universidade Técnica de Lisboa;

12. LANDIN, D., CARTER, J. (1992). Student thoughts during tennis instruction, Journal of Teaching in Physical Education, 3 (11), 256-267, USA, Illinois;

13. LOCKE, L., JENSEN, M. (1974). Thought sampling: A study of student attention through self-report, The Research Quarterly, 3 (45), 263-275, USA, New York;

14. MARCELO, C. (1994). Formación del profesorado para el cambio educativo, Barcelona: PPU;

15. MARSH, H. (1990). The structure of academic self-concept: The Marsh/Shavelson model, Journal of Educational Psychology, 4 (82), 623636, USA, New York;

16. MARSH, H. (1992). Content specificity of relations between academic achievement and academic self-concept. Journal of Educational Psychology, 1 (84), 35-42, USA, New York;

17. NUNES, W. (2004). Análise de duas metodologias de ensino diferenciadas na aprendizagem de uma técnica desportiva: Estudo de variáveis mediacionais cognitivas, afectivas e motoras associadas aos alunos. Dissertação de Doutoramento não publicada, Faculdade de Motricidade Humana, Universidade Técnica de Lisboa;

18. PIÉRON, M. (1999a). Situación actual de la investigación educativa en el marco de la educación física escolar. Actas del primer congreso internacional de educación física "La educación física en el siglo XXI", 379401, Jerez: Fondo editorial de Enseñanza; 
19. PIÉRON, M. (1999b). Para una enseñanza eficaz de las actividades físicodeportivas, Barcelona: INDE;

20. PIERON, M., DELFOSSE, C., LEDENT, M., CLOES, M. (1997). Attitude des élèves face à l'école et au cours d'éducation physique, âge et retard scolaire, Revue de l'Education Physique, 1 (37), 31-41, France, Paris;

21. PIERON, M., DELFOSSE, C., LEDENT, M., CLOES, M. (2000a). Que pense l'élève de la leçon qu'il vient de vivre?, Revue de l'Education Physique, 3 (40), 119-129, France, Paris;

22. PIERON, M., LEDENT, M., DELFOSSE, C., CLOES, M. (2000b). Mieux connaître les élèves: Les motivations, Revue de l'Education Physique, 1 (40), 35-43, France, Paris;

23. ROBERTS, G., BALAGUE, G. (1989). The development of a socialcognitive scale of motivation, Communication to the Seventh World Congress of Sport Psychology, Singapore, July;

24. ROBERTS, G., TREASURE, D., BALAGUE, G. (1998). Achievement goals in sport: The development and validation of the perception of success questionnaire, Journal of Sports Sciences, 16, 337-347, United Kingdom, London;

25. RYAN, S., FLEMING, D., MAINA, M. (2003). Attitudes of middle school students toward their physical education teachers and classes, Physical Educator, 2 (60), 28-42, USA, Urbana, IL;

26. SHIGUNOV, V. (1991). A relação pedagógica em educação física: Influência dos comportamentos de afectividade e instrução dos professores no grau de satisfação dos alunos, Dissertação de Doutoramento não publicada. Faculdade de Motricidade Humana, Universidade Técnica de Lisboa;

27. SIEDENTOP, D. (1998). Aprender a enseñar la educación física, Barcelona: INDE;

28. SIMÕES, M. (1994). Investigações no âmbito da aferição nacional do Teste das Matrizes Progressivas Coloridas de Raven (M.P.C.R.), Dissertação de Doutoramento não publicada. Faculdade de Psicologia e de Ciências da Educação, Universidade de Coimbra;

29. SOLMON, M., BOONE, J. (1993). The impact of student goal orientation in physical education classes, Research Quarterly for Exercise and Sport, 4 (64), 418-424, USA, New York;

30. STELZER, J., ERNEST, J., FENSTER, M., LANGFORD, G. (2004). Attitudes toward physical education: A study of highschool students from four countries - Austria, Czechrepublic, England, and USA, College Student Journal, 2 (38), 171-178 USA, Michigan;

31. TZETZIS, G., GOUDAS, M., KOURTESSIS, T., ZISI, V. (2002). The relation of goal orientations to physical activity in physical education, European Physical Education Review, 2 (8), 177-188, United Kingdom, Chester;

32. WITTROCK, M. (1986). Students' thought processes, In M. Wittrock (Ed.), Handbook of research on teaching (3rd ed.), New York: Macmillan Publishing Company, 297-314;

33. WOOLFOLK, A. (2000). Psicologia da educação (7 $7^{\mathrm{a}}$ ed.), Porto Alegre: Artes Médicas Sul. 